\title{
Challenges in measuring the impact of Market Information Systems
}

\author{
John Staatz ${ }^{1}$ \\ Andrew Kizito ${ }^{2}$ \\ Michael Weber ${ }^{1}$ \\ Niama Nango Dembélé ${ }^{3}$ \\ ${ }^{1}$ Michigan State University \\ Department of Agricultural, Food, \\ and Resource Economics \\ Justin S. Morrill Hall of Agriculture \\ 446 W. Circle Drive \\ East Lansing \\ MI 48824-1039 \\ USA \\ <staatz@anr.msu.edu> \\ $<$ webermi@msu.edu $>$ \\ ${ }^{2}$ Makerere University \\ PO Box 7062 \\ Kampala \\ Uganda \\ <amuganga@isae.mak.ac.ug> \\ ${ }^{3}$ Ministre délégué auprès du ministre \\ du Développement rural, \\ chargé de l'Élevage, de la Pêche \\ et de la Sécurité alimentaire \\ Mali \\ $<$ dembele@msu.edu $>$
}

\begin{abstract}
Evaluation of the impact of investments in agricultural market information systems (MIS) on market performance faces several methodological challenges. These include: (a) defining the dimensions of market performance to measure (which is a function of whom the MIS is designed to serve) and identifying reliable indicators of performance dimensions; (b) identifying the pathways through which improved market information affects these dimensions of performance; (c) establishing a reliable baseline against which to measure improved performance; (d) distinguishing between investments in MIS and general improvements in information availability; (e) assessing the contribution of complementary investments and policy changes that frequently accompany the creation of MIS; (f) establishing a credible counterfactual concerning the market situation that would have prevailed in the absence of the MIS; and (g) interpreting the validity of stakeholders' statements and governments' revealed preferences, regarding the utility of MIS. Many of these challenges arise because improved market information can affect the welfare of market actors through improved market polices and increased competition, even if these actors do not have direct access to that information. This article discusses these challenges and identifies approaches that may be useful in developing a "convergence of evidence", concerning whether investment in a given MIS is socially worthwhile.
\end{abstract}

Key words: food policies; impact assessment; market information services; market transparency.

Thèmes: économie et développement rural ; méthodes et outils.

\section{Résumé}

Évaluation de l'impact des systèmes d'information de marché : défis méthodologiques

L'évaluation de l'impact des investissements dans les systèmes d'information de marché (SIM) sur la performance du marché est confrontée à plusieurs défis méthodologiques. Il s'agit notamment de : (a) définir les dimensions de la performance du marché à mesurer (qui est une fonction des groupes cibles à qui le SIM est destiné) et identifier des indicateurs fiables de ces dimensions; (b) identifier les voies par lesquelles les informations améliorées influencent ces aspects de la performance ; (c) établir un niveau de référence permettant de mesurer les performances améliorées ; (d) faire la distinction entre les investissements dans les SIM et l'amélioration de la disponibilité de l'information en général; (e) évaluer la contribution des investissements complémentaires et des changements politiques qui accompagnent souvent la création d'un SIM ; (f) établir un scenario hypothétique crédible de la situation du marché qui aurait prévalu en l'absence du SIM ; et (g) interpréter la validité des déclarations des parties prenantes et les préférences révélées des gouvernements quant à l'utilité des SIM. Un grand nombre de ces défis découlent du fait qu'une meilleure information de marché peut affecter le bien-être des acteurs du marché à travers leurs impacts sur les politiques de marché et sur le niveau de concurrence, même si ces acteurs n'ont pas un accès direct à cette information. Cet article examine ces défis et propose des approches qui peuvent être utiles dans 
l'élaboration d'une " convergence d'évidences " permettant de déterminer si l'investissement dans un système d'information donné est socialement rentable.

Mots clés : évaluation de l'impact ; politique alimentaire ; service d'information de marché ; transparence du marché.

Subjects : economy and rural development; tools and methods.

\section{Problem statement}

Although investment in agricultural market information systems (MIS) in low- and middle-income countries has increased rapidly since the late 1980s, there have been very few assessments of their impact on farmer incomes and overall market performance (Tollens, 2009). The lack of solid assessments reflects, in part, methodological difficulties in measuring and valuing the multiple ways that MIS potentially can affect market performance. This article describes the different dimensions of market performance that MIS attempt to influence, the pathways by which they can do so, and the challenges these pose for evaluating impact.

For the purposes of this article, an agricultural MIS is defined as an organization or a group of organizations that: (1) collects data on market conditions; (2) processes and analyses the data in order to transform it into market information; and (3) disseminates market information products to different stakeholders using one or more channels ${ }^{1}$. Market information products include: (1) market news (e.g. information on prices, quantities, market conditions, and business contacts); (2) market analytical reports (e.g. reports that analyze factors that cause changes in market conditions and their effects on stakeholders); and (3) business reports (e.g. providing information that can help stakeholders identify reliable trade partners). Not all MIS produce all these products. The MIS may be based in the public-sector,

\footnotetext{
${ }^{1}$ Market data are measurements of market conditions that attempt to capture reality quantitatively or qualitatively. Information is data that have been processed, organized, interpreted and communicated to provide utility for a specific decision or problem context.
}

private-sector, farmer and trader organizations, or NGOs. MIS stakeholders include MIS personnel, farmers, traders, processors, government policy analysts and policy makers, development organizations, input providers, banks, and researchers who directly or indirectly express the needs for MIS information products.

The unit of analysis in this article is the MIS, as defined above, and not the presence of an ICT (e.g. cell phones, internet, or radio), which is considered here as one of the channels through which improved agricultural market information is disseminated to different stakeholders. An important contribution of this article is the distinction between an MIS that produces improved agricultural market information and the use of ICT to transmit and diffuse improved information products to different stakeholders. This distinction makes this report different from others that have investigated the role of ICT availability on market performance (Aker and Mbiti, 2010; Donner and Escobari, 2010; Jensen, 2010). Another emphasis of this article is the distinction between access to market information (and the implied use of proxies such as ownership of a radio or presence of a cell phone network) and reception of market information, as well as their implication on measuring the effects of information on market performance.

\section{Background}

Over the past 30 years, interest and investment in agricultural MIS in low- and middle-income countries has increased sharply, due to at least three reasons. First, there has been recognition that the structural transformation of the economy that accompanies economic development involves increased integration of the economy across time, space, and different sectors of the economy. This increased integration implies increased economic coordination, of which information is a key input (Hayek, 1945). Second, since the structural adjustment era of the 1980s and 1990s, most countries have moved towards market processes and away from central planning, government administered pricing, and parastatal marketing systems in order to provide such coordination (Rashid et al., 2008). MIS were seen as one way of increasing transparency (i.e. reducing information asymmetries among traders, small-scale farmers, consumers, and government) in the newly liberalized markets, thereby offering some protection to the more vulnerable actors in the system (Tollens, 2009). There was also a belief in some countries, such as Mali, that improved market information could provide market stability that national grain boards had not been able to ensure because they lacked the resources to defend floor and ceiling prices (Dembélé and Staatz, 2002). Third, the ICT revolution has dramatically reduced cost and expanded access to a wide variety of information for economic actors, thereby creating new potential data collection, information delivery, and cost-recovery mechanisms for MIS, offering the promise of lower costs, broader reach, and greater financial sustainability. As a result, the number and variety of programs aimed at improving farmers' access to agricultural market information in low-income and transition economies has skyrocketed in the last 10 years. For example, a 2009 
joint CIRAD-MSU survey identified 49 MIS initiatives in 19 Sub-Saharan African countries. Whereas MIS created from the 1980s through to the early 2000s, particularly in sub-Saharan Africa, were typically state-run efforts focused primarily on price reporting (Rakotoson et al., 2010), an array of alternative institutional models has emerged since the mid-2000s. These include: MIS housed in or run by farmer organizations (e.g. Observatoire du Marché Agricole in Mali, Economic Information System of Vegetables in Madagascar, and Zambia National Farmers Union SMS 4455 in Zambia), private-sector systems that offer the promise of financial sustainability through the sale of information to users, typically through SMS and specialized reports (e.g. Esoko Ghana, Infotrade in Uganda, KACE Market and Information Linkage System in Kenya, and Reuters Market Light in India), and agricultural exchanges, such as the Ethiopia Agricultural Exchange, which generate some aspects of market information as a by-product of their facilitation of open and forward-market trading. Examples of Public MIS include the Agricultural Market Information Center in Zambia, Siarm in Senegal, the Agricultural Market Information System in Mozambique, Information System of Agricultural Markets in Niger, Information Systems on Livestock Markets in Niger, and the System of Agricultural Information Products Guinea (SIPAG) in Guinea Conakry. Of the clientele, there is little variation with regards to the top three who are served according to the different types of MIS (farmers, traders, and government) among different MIS models (Kizito, 2011).

Even the MIS that generate revenues through user fees (such as charges for receipt of market information via SMS) typically require substantial initial funding from outside sources, such as governments or donors. In part, this reflects normal start-up costs of any enterprise, but more fundamentally, reflects non-appropriability, indivisibility, and ex-ante uncertainty which characterize many types of market information and which lead the private sector to under-invest in it (Kizito, 2009). Thus, the outside providers of funds seek ways to evaluate the payoffs to these investments and doing so firstly requires clear delinea- tion of which dimensions of market performance may be improved by MIS.

\section{What do we mean}

\section{by market performance? What are MIS \\ intended to influence?}

Investment of public funds in MIS has historically been justified based on the three factors developed below (Henderson et al., 1983).

\section{- A more equitable distribution of bargaining power within the food system}

Politically, the desire to "level the playing field" among actors was the motivation for the creation of price reporting systems in many countries, including the US. While framed primarily in terms of income redistribution (reduction of monopsony rents accruing to large-scale buyers in the system), the argument implicitly also has economic efficiency and growth justifications:

- In the short run, moving the market from a position of monopsony or oligopsony to a more competitive outcome, due to provision of improved agricultural market information, should expand output and reduce dead-weight loss. This might occur, for example, as a result of farmers organizing group marketing in response to knowledge of better prices in other markets; even if the threat of creation of such group marketing efforts is credible, it may improve the relationship between bargaining partners of farmers and traders. This is most likely the case when farmers have a storable commodity and access to finance in order to be able to hold off selling the product while they search for other markets. In practice, however, the size of the efficiency gains, moving towards more competitive market structures, tend to be small relative to the size of the rent redistribution (Azzam and Schroeter, 1995), implying that the latter may be driving the political demands for creation of MIS.
- In the long run, the argument is based on the fact that higher prices for farmers will induce greater production. The magnitude of the supply response, however, depends on the price elasticity of supply and hence the factors that determine it, such as farmers' access to additional inputs (and hence the financing to attain them), improved technologies, and risk management tools. The greater the supply elasticity, ceteris paribus, the greater the return to improved market information (Kizito, 2009). But if this increase in prices for farmers simply represents a redistribution of rents from other actors in the system (e.g. large-scale traders), then the increase in farm-level production needs to be weighed against the loss in production elsewhere in the economy that would have been engendered by the higher trader income (e.g. through the linkage effects emanating from the higher trader incomes). Whether redistribution of rents from large-scale traders towards smaller actors (consumers and small-scale farmers and traders) leads to more rapid economic growth thus depends on the marginal propensity of the different actors to invest domestically rather than consume their additional income, the marginal productivity of investment of the different actors, and the indirect (linkage) impact their changed investment and consumption patterns engender.

\section{- Improved market efficiency from better private decision-making}

This argument for investing in improved information has received the most attention from economists, with interest focused on improving efficiency both in the short term and the long term:

- In the short run, better information can lead to better spatial and temporal arbitrage (including discovery of new markets) of existing production through the reduction of search costs (Stigler, 1961).

- In the long run, more informed decision-making by farmers, traders, processors, and consumers can lead to better allocation of resources over time through the adjustment of production and consumption, in order to respond more closely to consumers' effective demands and to the opportunity costs of the resources involved 
in the production of those goods. Kizito (2009) describes these effects of improved information, which reduce the dead-weight loss when farmers and small-scale traders with rational expectations respond to improved price forecasts from MIS, as a reduction in the costs of being off the equilibrium price. Their magnitude depends not only on the price elasticity of supply, as discussed above, but also on the price elasticity of demand. The more inelastic the demand, the higher the marginal costs of being out of equilibrium (i.e. the greater the disutility to consumers of having too few or too many goods), and hence the greater the payoffs, ceteris paribus, to improved market information. In the long run, the adjustment in supply is based on private actors who have an improved information base to assess investment opportunities in the agrifood system. The magnitude of the impact of improved longer-term investment decisions is likely to be much higher than the short-run efficiency gains brought about by better allocation of existing supplies; however, they are much more difficult to estimate.

- These efficiency effects in the longrun can include expansion of markets through reduction of transaction costs, gains from specialization induced by the broadening and increased reliability of the market (at the level of individual farmers, zones within a country, and across countries), the expansion of credit to farmers and traders by allowing lenders to assess more accurately the value investments and working capital aimed at expanding agricultural production and trade, and the development of new, more efficient exchange arrangements made possible through the availability of improved information (e.g. formula pricing based on verifiable prices in key reference markets).

\section{- Improved design and implemen- tation of government programs and technology development}

Providing an improved information base for public policies and programs was a major motivation for the creation of price reporting systems in the US (where the first public price reporting system was implemented to monitor compliance with pricecontrol regulations during World War I) and in the Sahel, where several
MIS were created to track the impact of structural adjustment programs (Dembélé and Staatz, 1989; Henderson et al., 1983). The role of MIS in informing public policies and providing the information to implement public programs (such as deficiency payment schemes in the US) continues to be a major motivation for public support of MIS. For example, Mali's Council of Ministers requests weekly reports from the country's agricultural market information system and uses these reports for making food policy decisions, such as setting the level of taxation on rice imports. In addition, having accurate information about the market value of different commodities is essential in carrying out financial and economic analysis of technologies developed by agricultural research systems. If analysts focus solely on the direct benefits of improved market information to private actors, while ignoring the potential impact of improved information on better public policies, they will likely underestimate the benefits of such information. But as described below, constructing a credible counterfactual of what policies would be without such information is extremely challenging.

\section{Challenges in}

\section{assessing the impact of investments in MIS}

There are two major categories of challenges in assessing the impact of investments of MIS: (a) choosing appropriate impact indicators; and (b) identifying the causal effects of the MIS.

\section{Choosing the impact indicators}

Economists studying agricultural markets typically use a number of different indicators to assess market performance. Some involve changes in market structure, such as an increased number of market entrants, which should lead to increased competition. Others involve reduction in marketing margins and measures of broader economic integration, such as a reduction of spatial and temporal price volatility (Shahidur, 2004; Jensen, 2007; Aker, 2010), which are hypothesized to benefit both farmers and consumers. Still, others try to infer the impact of market changes on prices received by some groups of actors (e.g. small-scale farmers) for their products and/or prices paid for their inputs (Svensson and Yanagizawa, 2009; Svensson and Drott, 2010), as well as increased incomes by selected target group(s), including both the immediate impact of the more favourable prices and the group's supply response to them (Goyal, 2010). Finally, some indicators attempt to measure the impact of market changes on overall aggregate economic welfare, as measured by changes in economic surplus (Kizito, 2009).

Identifying the appropriate indicator to use for the assessment of MIS performance is a function of whom the MIS is designed to serve, as different users (small vs large-scale farmers, small vs large-scale traders, government policy makers, and consumers) each have different objectives and hence different information needs. For example, one critical characteristic of market information is its timeliness. For a policy analyst interested in the long-term evolution of prices in the horticultural market, monthly average tomato prices may be entirely satisfactory. For a trader trying to decide where to send tomatoes the next day, such prices are worthless and an option that allows a more accurate forecast of tomorrow's prices in alternative markets is required, rather than current prices (Bowbrick, 1988). Thus, for the assessment of payoffs for investment in MIS, one should always question what the goal is.

As one moves from the more narrowly defined impact indicators, such as changes in prices received, to more broad and long-term effects on economic output, the challenges of establishing credible lines of causality become greater for reasons discussed below. Yet, it is this broader transformational impact on the economy that presumably are the strongest

\footnotetext{
${ }^{2}$ Natsios makes the point generally that investments that have the broadest transformational effects on development are those that are most difficult to evaluate.
} 
motivation for investing in improved market information (Natsios, 2010) ${ }^{2}$. If one argues that the MIS's aim is to improve several different dimensions of performance (higher prices, better distribution of income, and faster economic growth), then one is faced with the problem of assigning weights to these different dimensions, which is the equivalent of determining which stakeholders' interests are of importance - a difficult but inevitable choice in MIS design (Dembélé and Staatz, 1989).

\section{Identifying the causal effects of the MIS}

Once the impact indicators have been chosen, there are several challenges in identifying whether, and how much, MIS activities have caused changes in the levels of those indicators.

\section{Establishing a baseline}

In any ex-post analysis (as opposed to a randomized experimental approach) of the impact of MIS activities on the level or dispersion of prices, baseline measurements of those indicators prior to the creation of the MIS are required. Yet, it is the lack of reliable data on agricultural prices, particularly at the farm level, that typically motivates the creation of the MIS. Where data exist regarding such prices prior to the creation of the MIS, a lot of "noise" is typically present, in part, because of inconsistent methods used in collecting the data. Therefore, it is not clear whether studies that purport to show that the MIS reduces price volatility, for example, are truly measuring a reduction in volatility or merely reflect measurement error.

\section{Measuring treatment effects}

In the context of MIS evaluation, "treatment effects" refer to the effects of receiving information from MIS on market participants. Most often, proxies may be observed, such as ownership of a radio or cell phone (a channel through which MIS can transmit information, but not reception or use of MIS information per se). This does not pose a problem if the purpose of the analysis is to estimate the effect of ICT, but it becomes a problem if one wants to estimate the effect of an MIS using ICT, because the ICT may itself have effects on the outcomes under study. Indeed, three of the most widely cited recent studies on the impact on market performance of improved access to market information via cell phones (Jensen, 2007; Aker, 2008; Aker, 2010), do not examine dedicated MIS investments, but rather the impact of cell phone coverage in general. In the MIS literature, Svensson and Yanagaziwa (2009; 2010) are, to our knowledge, the only authors to have tackled this problem by applying a difference-in-difference approach to treatment and control groups when MIS information began to be diffused by radio in Uganda ${ }^{3}$.

\section{Endogenous placement of the treatment}

Evaluating impact is complicated if the MIS "treatment" is contemporaneous with other activities that affect both reception of the MIS information and the ability to act upon it (a time trend bias) or if those who receive MIS information are non-random (selection bias, as discussed in Todd 2007).

Complementarity of investments in improved information and other actions

The value of information depends on actors' ability to act upon it. Thus, the payoffs to improved information depend on the level of complementary investments in elements such as improved access to factor and credit markets, access to farmer advisory services, processing technologies that allow consumers to shift consumption patterns more easily as relative prices change, and the overall policy environment (i.e. the factors that condition the supply and demand elasticities mentioned above). Many of the MIS established in Sub-Saharan Africa in the 1980s and 1990s were created as part of broader packages of market reforms and infrastructure investments. Since other components of the reforms (such as withdrawal of state marketing boards from direct buying and selling in the wholesale trade, opening of export markets,

$\overline{3}$ Hong (2010) uses a similar approach to study the impact of Napster on music downloads. programs to improve traders' and farmers' access to credit, and improvements in road infrastructure) were contemporaneous with the creation of the MIS and affected all farmers, it is difficult to differentiate between the impact on market performance of improved access to market information and the elements of the reform. Indeed, if these elements were perfect complements, it is theoretically impossible to estimate the marginal contribution of the individual elements of the package. In such a situation, one can only evaluate the returns to the entire reform package, rather than to the individual elements. One way around the time-trend bias is to try to identify natural experiments where only market information access has changed in a relatively short period while other underlying conditions have remained the same. The few studies that have attempted to do this (Jensen, 2007; Aker, 2008; Aker, 2010; Svensson and Yanagizawa, 2009; Goyal, 2010) have, with one exception, focused on private-sector efforts to improve access to information, as these were typically not part of broader policy reforms.

Non-random placement of treatment At the household level, many of the factors that affect the ability to act on market information (wealth and access to financial and input markets) may also be correlated with access to information (e.g. ownership of a radio or residence in an area served by an MIS). This selection bias, if not recognized and taken into account in the analysis, leads to overestimates of the impact of MIS activities on performance outcomes.

Researchers have used a number of different techniques to deal with this selection bias treatment effect. For pilot programs where researchers can work with MIS providers in order to structure the introduction of MIS services in an explicit experimental design, such as the introduction of cell phone-based MIS access, both randomized experiments and regression discontinuity approaches can address both the "complementarity" issue described above and selection bias. Such approaches are not suitable, however, to measure the impact of MIS implemented at a national level or identify the effects of policy 
improvements resulting from better market information and affect all actors in the market (discussed below). In situations where only a quasiexperimental design is possible (e.g. in the case of natural experiments, where one area receives MIS broadcasts and another does not, or where baseline measures are available on the impact indicators of interest before the operation of the MIS and measured afterwards), propensity score matching and difference-in-difference (DiD) approaches are among the potential tools to deal with the problems outlined above.

Yet, these approaches, as, as well as randomized experiments, still may not capture the full impact of investment in improved information because of the spillover effects of improved market information services on all actors in the market through increased competition, whether or not they have had direct access to MIS services. This is particularly true if the MIS, through its provision of better information to policy makers, leads to an improved policy environment for agricultural growth or if, by providing information to some actors, it improves market performance (e.g. driving the prices to more competitive levels) in a way that benefits even those who do not receive the MIS information. For example, the DiD estimator is defined as the difference in average outcome (e.g. in prices received) in the treatment group (e.g. farmers receiving market information) before and after treatment minus the difference in average outcome in the control group (those not receiving information) before and after treatment. The basic idea is that any change in outcome, not associated with the individual's access to improved information from the MIS, is attributed to factors other than the MIS. However, if the MIS has been successful in improving the policy or competitive environment, the benefits would accrue to all market actors, not just those with individual access to the MIS reports. Hence, the DiD approach would underestimate the impact of the

\footnotetext{
${ }^{4}$ The same is true for propensity-score-matching approaches. Of course, if a poorly functioning MIS led to worse policy, then these approaches would overestimate its positive impact on market performance.
}

MIS $^{4}$. The same argument would hold even if the policy environment remained unaffected by the MIS but the improved access to information by the treatment group led to the market behaving more competitively, thereby benefiting the control group as well.

The problem of establishing the counterfactual becomes more difficult the longer the period under analysis, as the potential long-term impact of improved information on the policy environment, innovation in contracting arrangements, and farmer and trader strategies are complex.

\section{Interpreting stakeholder statements regarding improvements in information availability}

MIS sometimes rely on user assessment surveys, in which stakeholders are asked to report on the quality of information provided by the MIS and its impact, in order to assess the quality of MIS services. These surveys have several shortcomings. These include the risk that: (a) respondents tell the enumerators what the respondents believe the enumerators want to hear ${ }^{5}$; and (b) the MIS could indirectly be improving market performance in ways discussed above, even though the respondents do not perceive that they are directly receiving the MIS reports or finding them useful. These types of user surveys may be more useful to identify the types of information that users want but are not currently receiving from the MIS (for example, information on regulations governing cross-border trade), rather than to draw definitive conclusions on the adequacy of current MIS services.

\section{Interpreting revealed preferences of stakeholders to invest in MIS}

One possible indication of the usefulness of MIS services is whether local stakeholders, including government, are willing to continue to finance them

\footnotetext{
5 Bowbrick (1988) notes that during the 1980s, respondents to surveys about the adequacy of MIS surveys in Eastern Europe and Southwest Asia often reported very positive current ratings for MIS that had ceased to exist several years earlier.
}

once external support is withdrawn. MIS, particularly sub-Saharan Africa, have frequently collapsed once external assistance has disappeared, and even "private-sector" MIS continue to be heavily dependent on external funding (Kizito, 2009; Tollens, 2009; Rakotoson et al., 2010). The failure to invest the government's own resources in MIS likely indicates that the government judges the services to be unworthy of the cost (directly to either government or politicallyimportant stakeholders) and should be taken seriously as a possible indicator of MIS value. There are, however, potential problems with this indicator. In the early stages of development of information and analytic services, there is often a need to educate stakeholders on the use of the information, without which they do not find it valuable. Focusing simply on generating market data, without investing adequately in transforming these data into useful information for stakeholder decision-making or carrying out outreach in order to demonstrate the usefulness of such information, may lead to the perception that the MIS is not worth the cost. It is also possible that those who benefit from the MIS (e.g. small-scale farmers) do not have a sufficiently loud voice in the political system to have their preferences counted.

The opposite is also possible. The willingness of domestic stakeholders (e.g. via government) to support the MIS for local budgets should be considered an important, but not infallible, indicator of the revealed preference of stakeholders, regarding the value of MIS services. When the support is provided by private actors (as was the case for the Malian MIS in the Office du Niger in 1988, when government funding ran out at the end of the year and rice farmer cooperatives provided interim support for information collection and diffusion), it is a strong indicator of the perceived value of the services. When government provides support, it may also be a strong indicator of perceived value, but the history of bureaucracies around the world also shows that many government-supported agencies have succeeded in mobilizing support by providing services to a select group of beneficiaries, even when the overall costs to society of 
the agencies exceed the benefits (Bartlett, 1973).

\section{Ways forward}

Given the challenges discussed above, evaluation of the impact of investments in MIS requires a "preponderance of evidence" approach, drawing on multiple indicators, rather than relying on a single approach. In particular, it should be recognized that estimates of rates of return (ROR) to investment in MIS and similar estimates of aggregate economic impact of such investments depend heavily on assumptions about supply and demand elasticities, which, for the long-run, in turn, embody numerous assumptions about the indirect impact of MIS on the evolution of government policies and private investment decisions. While plausible arguments can be made that high-quality information can have important impacts on policy and investment decisions, it is difficult to provide credible ex-ante (and even ex-post) estimates of how a specific MIS affects such decisions, making ex-ante ROR estimates subject to large margins of error.

In developing a "preponderance of evidence" approach, the following points should be kept in mind:

- MIS are highly heterogeneous, serving multiple stakeholders with multiple objectives. Thus, the same set of evaluation criteria is unlikely to apply to all MIS. For example, some recent discussions of publicly supported MIS have focused on their perceived shortcomings in serving certain farmers and traders, while ignoring a major motivation for their creation was to improve public-sector decisionmaking. Therefore, the first step in evaluation is to identify what the stated objectives and targeted stakeholders of the MIS are in order to come up with a set of evaluation criteria. An effort should also be made to investigate the unintended consequences of the MIS, both positive and negative.

- Close attention to evaluation of the incentive structure within a particular MIS to provide and preserve the quality of information reported is also required. This includes examination of issues such as: the use of consistent, clear and market-relevant definitions of products and market levels (farmgate, assembly, wholesale, retail, etc.); quality control on data collection, entry, processing and analysis; and incentives for strategic misreporting of prices by respondents ${ }^{6}$.

- It is important to differentiate between improvements in information access in general (e.g. through the spread of cell phones) and dedicated MIS investments. The two may be complementary, but demonstrating returns to information in general does not prove that MIS investments are worthwhile.

- In evaluating various MIS and broader investments in improving access to information, it is important to recognize the potential complementarity among the various approaches. For example, radio broadcasts of MIS reports may prompt private actors to turn towards cell-based systems in order to gather additional market information that, in turn, leads to better decision-making. Even if the actors report that the information gathered by cell phone is the basis of their business decision, it would be incorrect to say that the MIS had no value in leading to that decision. Similarly, in much of the world, private market information services (including analytic services) base their work on publicly collected data, adding value through further analysis and packaging (Aldridge, 1992).

- Where possible, natural experiments or randomized trials, in which some groups have access to improved market information while others do not (such as the roll-out over time of MIS radio broadcasts or cell-phone coverage), are useful in order to try to compare between situations with and without market information. Yet, analysts should recognize that these approaches are likely to yield minimum estimates of the returns to improved information, as they focus on the short-term private benefits of direct access to the information. The longer-term dynamic effects that can result from improved market performance, resulting from better government policies and increased

\footnotetext{
${ }^{6}$ The latter may be a particular problem in wikibased approaches when there are few people reporting prices in the system. Wiki-based approaches rely on a large number of participants to "self-correct" errors.
}

competition that benefits even those who do not have direct access to the information, are overlooked.

- Despite some of the caveats raised above, some reliance on willingness to pay (particularly by the public sector) is a useful indicator of MIS value. Rather than unconditional donor support for such systems (which may crowd out public and other stakeholder funding), some progressive withdrawal of donor support over time is likely to provide evidence of whether such programs are valued by government and other beneficiaries. Nonetheless, given the "public good" characteristics of some types of market information, it is unlikely that private funding alone will provide a socially optimal level of market information.

- In evaluating different models of MIS, particularly between "public" and "private-sector" MIS, it is important to distinguish between funding models and models of service delivery. Private-sector firms can, under contract with the public sector, provide MIS services. For ex-ante evaluation of potential investments in MIS, therefore, focus should be made on the type of services desired, the incentive structure in different types of MIS to deliver these high-quality services, and the potential institutional arrangement (including possible private-public partnerships) used to deliver them, rather than a dogmatic approach favouring either "private" or "public" MIS.

\section{Acknowledgements}

The authors thank the two anonymous reviewers for their very helpful comments on an earlier version of this paper.

\section{References}

Aker JC, 2010. Information from Markets Near and Far: Mobile Phones and Agricultural Markets in Niger. American Economic Journal: Applied Economics 2 : 46-59.

Aker JC. Does Digital Divide or Provide? The Impact of Cell Phones on Grain Markets in Niger. 2008.

Aker JC, Mbiti IM, 2010. Mobile Phones and Economic Development in Africa. Journal of Economic Perspectives 24 : 207-32.

Aldridge K. A Framework for Analyzing Alternative Institutional Arrangements for the Cereals Market 
Information System in Mali. East Lansing: Michigan State University, 1992.

Azzam AM, Schroeter JR, 1995. The Tradeoff Between Oligopsony Power and Cost Efficiency in Horizontal Consolidation: An Example from Beef Packing. American Journal of Agricultural Economics $77: 825-36$.

Bartlett R, 1973. Economic Foundatins of Political Power. New York: The Free Press.

Bowbrick P, 1988. Are Price Reporting Systems of Any Use. British Food Journal 90 : 65-9.

Dembélé NN, Staatz JM. The Impact on Market Reform on Agricultural Transformation in Mali. In: Jayne TS, Minde IJ, Argwings-Kodhek G, eds. Perspectives on Agricultural Transformation: A View from Africa. Jericho (NY, USA): Nova Science Publishers, 2002.

Dembélé NN, Staatz JM, 1989. Market Transparency and the Role of the State: The Establishment of a Market Information System in Mali. East Lansing: Michigan State University.

Donner J, Escobari MX, 2010. A review of evidence on mobile use by micro and small enterprises in developing countries. Journal of International Development $22: 641-58$

Goyal A, 2010. Information, Direct Access to Farmers, and Rural Market Performance in Central
India. American Economic Journal: Applied Economics $2: 22-45$.

Hayek FA, 1945. The Use of Knowledge in Society. American Economic Review 35 : 519-30.

Henderson DR, Schrader LF, Rhodes VJ. Public Price Reporting In: Armbruster WJ, Henderson DR, Knutson RD, eds. Federal Marketing Programs in Agriculture: Issues and Options. Danville (Illinois, USA): Interstate, 1983.

Jensen R, 2007. The Digital Provide: Information (Technology), Market Performance, and Welfare in the South Indian Fisheries Sector. Quarterly Journal of Economics 122: 879-924.

Jensen RT, 2010. Information, efficiency, and welfare in agricultural markets. Agricultural EConomics 41 : 203-16.

Kizito A, 2009. Estimating The Benefits From Improved Market Information. East Lansing: Michigan State University.

Kizito AM, 2011. The Structure, Conduct, and Performance of Market Information Systems in Sub-Saharan Africa. East Lansing: Michigan State University.

Natsios A, 2010. The Clash of the Counterbureaucracy and Development. Washington (DC): Center for Global Development.
Rakotoson J, David-Benz H, Egg J, F.Galtier, Kizito A, YY.Shen. What's New About MIS in SubSaharan Africa? An Overview of MIS Evolution. Agricultural Market Information Systems in Africa: Renewal and Impact. Montpellier, France, 29th to 31st March 2010. Cirad, Inra, MSU.

Rashid S, Gulati A, Ralph Cummings J, 2008. From Parastatals to Private Trade: Lessons from Asian Agriculture. Baltimore: Johns Hopkins University Press for the International Food Policy Institute.

Shahidur R, 2004. Spatial Integration of Maize Markets in Post-liberalised Uganda. Journal of African Economies 13 : 102-33.

Stigler GJ, 1961. The Economics of Information. Journal of Political Economy 69 : 213-25.

Svensson J, Drott DY. Tuning in the Market Signal: The Impact of Market Price Information on Agricultural Outcomes. 2010.

Svensson J, Yanagizawa D, 2009. Getting Prices Right: The Impact of the Market Information Service In Uganda. Journal of the European Economic Association 7(2-3).

Tollens EF. Market Information Systems in subSahara Africa: Challenges and Opportunities. Gold Coast, Australia, 2009. 